\title{
Tam Sayılı Programlama ve Simülasyon ile Raf Alanı Optimizasyonu: Bir Ambalaj Firmasında Uygulama
}

\author{
Ayten Yilmaz Yalçıner ${ }^{1 *}$, Burak Can $^{2}$
}

${ }^{1}$ Sakarya Üniversitesi, Mühendislik Fakültesi, Endüstri Mühendisliği Bölümü, Sakarya, Türkiye (ORCID: 0000-0001-8160-812X )

${ }^{2}$ Sakarya Üniversitesi, Mühendislik Fakültesi, Endüstri Mühendisliği Bölümü, İstanbul, Türkiye (ORCID: 0000-0002-3713-9714)

(Bu yayın HORA 2019 kongresinde sözlü olarak sunulmuştur.)

(İlk Geliş Tarihi 1 Ağustos 2019 ve Kabul Tarihi 25 Ekim 2019)

(DOI: 10.31590/ejosat.638609)

ATIF/REFERENCE: Yalçıner, A. Y. \& Can, B. (2019). Tam Sayılı Programlama ve Simülasyon ile Raf Alanı Optimizasyonu: Bir Ambalaj Firmasında Uygulama. Avrupa Bilim ve Teknoloji Dergisi, (Özel Sayı), 375-388.

\begin{abstract}
$\ddot{O} \mathbf{z}$
Depolama ve stoklama faaliyetleri işletmeler için zaman, alan ve maliyet açısından oldukça stratejiktir. Üretim hattının, akışının duraksamadan çalışması, tedariklerin zamanında ve uygun şartlar içinde yapılabilmesi, fire ve diğer kayıpların minimuma indirgenmesinin yanısıra üretim maliyetlerinin kontrolü gibi kritik konular depo yönetimi konusunu her geçen gün daha cazip hale getirmektedir. Depolama ile ilgili en önemli kararlardan biri ise malzemelerin raflara atama işleminin nasıl sağlanacă̆ıdır. İşletmenin temel kaynakları arasında yer alan, stok kalemlerinin depolandığı, ürünlerin sergilendiği araç olarak tercih edilen raflar etkin depo yönetimi için de stratejik bir araçtır. Raf yönetimi ve malzeme atamaları etkili bir şekilde yapıldığı taktirde üretimde süreklilik ve verimlilik sağlanacak, raflarda kullanılan ve kullanılmayan alanların optimizasyonu da mümkün olacaktır. Bu konuda stok alanlarını verimli şekilde kullanmak öncelikli amaç olarak görülmektedir. Bu çalışmada, malzemelerin stok alanında raflara, en çok alanı kullanabilir hale getirme prensibi dikkate alınarak atanması yoluyla nasıl yerleştirilebileceği araştırılmaktadır. Uygulama çalışmasının yapıldığı yer gıda ambalajı üreten bir firmadır. Firmanın yarı mamul deposunun kapasitesinin artırılması ve üretilen ürünlerin boyutlarına göre raf yerleştirme optimizasyonu gerçekleştirilmesi hedeflenmiştir. Bu amaçla firmadan birebir inceleme yoluyla elde edilen veriler kullanılarak öncelikle en verimli raf tipi tesbiti için Sırt Çantası modeli kullanılarak, daha sonra bu tesbit edilen raf tiplerinden kaç adet olması gerektiğini bulmak amacıyla Tam Sayılı Programlama tekniği kullanılarak raf alanı optimizasyonu gerçekleştirilmiştir. Amaç, 2 katlı raf sistemini işletmenin stok malzemesi olarak ele aldığı bobinlerin yarıçapları dikkate alınarak 3 katlı raf sistemine çevirerek alanın en verimli şekilde kullanılmasını sağlamaktır. Çalışmada aynı zamanda ProModel simülasyon programı ile firmanın mevcut ve önerilen sistemi de simüle edilmiştir.
\end{abstract}

Anahtar Kelimeler: Depo yönetimi, Raf Alanı Optimizasyonu, Tam Sayılı Programlama, Sırt Çantası Modeli

\section{Shelf Space Optimization with Integer Programming and Simulation Techniques and an Application in a Packaging Company}

\begin{abstract}
Storage and stocking activities are very strategic for enterprises in terms of time, space and cost. The critical issues such as operation of the production line, flow without hesitation, timely and appropriate conditions of supply, minimization of waste and other losses as well as control of production costs make warehouse management more attractive day by day. One of the most important decisions about storage is how to arrange the materials to be placed on the shelves. Shelves, which are among the main sources of the enterprise, where stock items are stored and which are preferred as the means of displaying products, are also a strategic tool for effective warehouse management. If shelf management and material assignments are made effectively, continuity and efficiency in production will be ensured, and optimization of used and unused areas on shelves will be possible. In this regard, using stock areas efficiently is seen as the primary objective. In this study, it is investigated how the materials can be placed on the shelves in the stock area by assigning the most space to use. It is studied in a company that produces food packaging. It is aimed to increase the capacity of the company's semi-finished warehouse and to optimize shelf placement according to the dimensions of the products produced. For
\end{abstract}

* Sorumlu Yazar: Sakarya Üniversitesi, Mühendislik Fakültesi, Endüstri Müh. Bölümü, Sakarya, Türkiye, ORCID: 0000-0001-8160-812X, ayteny@sakarya.edu.tr 
this purpose, the data obtained from the company through one-to-one analysis, firstly using the Knapsack model, one of the operational research techniques, for the most efficient shelf type determination, then the shelf space optimization was performed by using integer programming technique to find out how many of these determined shelf types should be. The aim is to ensure the most efficient use of the space by converting the 2-storey shelf system into a 3-storey shelf system considering the radii of the coils that the enterprise considers as stock material. At the same time, the current and proposed system of the stiuation has been simulated with the ProModel simulation program.

Keywords: Warehouse management, shelf space optimization, simulation, integer programming, knapsack model

\section{Giriș}

Her geçen gün lojistik sektörünün öneminin artması ve paralelinde artan ticaret hacmi, depo yerleşimi ve yönetimi alanındaki operasyonların doğru bir şekilde, en az maliyetle ve en hızlı şekilde gerçekleştirilmesinin önemini de artırmıştır. Ayrıca işletmeler mevcut malzeme ve ürünlerin stokta bulunması yada bulunmaması halinde katlanılacak maliyetin en aza indirgenmesi ve depo alanından en fazla avantajı sağlamak gibi amaçlar için etkin bir stok kontrolü sağlamak istemektedirler.

Deponun iki temel işlevi malların geçici olarak depolanması ve korunması ile kişisel sipariş isteklerinin yerine getirilmesi, malların ambalajlanması, satış sonrası hizmetler, onarımlar, test, muayene ve montaj gibi katma değerli servisler verilmesidir. Bir depo alanının tasarımı depo süreçleri, depo kaynakları ve depo organizasyonları arasında birbiriyle ilişkili çok sayıda karar içerdiği için oldukça karmaşık bir problemdir. (Heragu vd., 2005)

Depo yerleşimi ve yönetimi konusunda literatürde çok farklı alanlarda gerçekleştirilmiş çalışmalar bulunmaktadır. Depo tasarımından, raf aralıklarının tespitine, optimal stoklama-saklama kutularının ve palet sayılarının hesaplanmasından depo alanı yerleşim kararına kadar çok çeşitli alanlarda çalışmalar yapıldığı görülmektedir. Literatüre bakıldığında hem üretim işletmeleri için hem de perakende ve mağazacılık kapsamındaki işletmetler için gerçekleştirilmiş çalışmalar görülmektedir.

Depolama alanı optimizasyonunda Kang ve arkadaşları (2012) genetik algoritma ile üç boyutlu kutu paketleme problemini ele aldıkları bir çalışma yapmışlardır. Bu çalışmada depolama alanı optimizasyonunda ambalajlanmış ürün sayısının en üst seviyeye çıkarmak istenmiştir. Çeşitli hacimlerdeki nesnelerin tek bir kutuya paketlendiği üç boyutlu bir kutulama problemi bir hibrit genetik algoritma yaklaşımıyla ele alıp, literatürdeki farklı çalışmaların sonuçları ile bir değerlendirme yapmışlardır.

Tekil ve Özkır (2016) benzer olarak çalışmalarında kutulama problemlerinde kullanılan algoritmaları incelemişlerdir. Küçük boyutlu kutuların hacim boyutunu göz önünde bulundurarak kullanılan konteyner sayısını en küçükleyerek, ve nesneye dayalı bir programlama dili olan Pyton ile geliştirdikleri algoritma ile atama problemi çözmeyi hedeflemişlerdir.

Depo tasarımı için yapılmış çalışmalara göz atıldığında, Ashayeri ve Gelders (1985)in simülasyon tekniği kullanarak iyi bir depo tasarımına dair gerçekleştirdikleri çalışma, Gray ve arkadaşlarının (1992) hiyerarşik bir tasarım yöntemi önerdikleri çalışma ve Van den Berg ve arkadaşlarının (1998) yoğun ve boş zamanlarda sipariş toplamayı kapsayan bir depo önerisinde bulundukları çalışmalar literatüre katkı sağlayan örnekler olarak verilebilir.

Depolama ile literatürde yer alan çalışmalardan görülmektedir ki en önemli kararlardan birisi de stok alanlarını verimli bir şekilde kullanabilmek için malzemelerin raflara atama işleminin en etkili nasıl yapılacağinın tesbitidir. Toplam taşıma maliyetini en küçükleyecek şekilde fazla hareket eden ürünlerin giriş çıkış noktalarına yakın yerleştirilmesi temel prensip olarak düşünülse de; şekil, ağırlık, değer, raf ömrü, üst üste yığılabilirlik ya da yığamama gibi malzeme özellikleri de dikkate alınmaktadır. Bu noktada matematiksel yada sezgisel modellerden destek almak daha olurlu çözüm sağlayabilir. Raf alanı optimizasyonu perakende sektörü için oldukça önemli bir konudur. Satış rakamlarının artması ve mali performanslarının iyileştirilmesi adına müşterinin dikkatini çekmek, ürünlerin optimal değerlendirilmesini ve en uygun şekilde raf yönetimini gerçekleştirmek isterler. Perakende sektöründe tahmin edilmesi zor parametre ve kısıtların olması sektördeki karar vericileri ve planlamacıları yeni yöntem ve metodları aramaya itmektedir. Janeiro (2014) Portekizli bir süpermarket zinciri örneğinden ilham alarak genetik algoritma tekniğinde rassal sayılı kodlama ile ürünleri en iyi konum ve karşılaşma sayısını tutarak raflara tahsis etmek ve satış rakamlarını bu sayede artırmayı amaçlamışlardır.

Gajar ve Adil (2011) yaptıkları çalışmada lineer kar fonksiyonu ile perakende raf alanı tahsisi problemi için en yakın komşu tekniği ile mevcut üç adet sezgisel çalışma ile kıyaslama yapmışlardır. Hwang ve arkadaşları, raf alanı tahsisi ve envanter kontrolü problemini çözmek için çalışmalarında konum ve talebe bağlı envanter seviyesinin etkilerini göz önüne alarak gradient arama sezgiseli ve genetik algoritma kullanarak bir model sunmuşlardır.

Depolama alanlarında farklı bir uygulama olarak Russel ve Urban (2010) ürünleri marka, lezzet, fiyat seti gibi çeşitli özellik esaslı olarak bir ailenin parçası olarak düşünen ilk yazarlardandır. Bu ailelerinin ürünleri bir arada tutulmalı ve estetik kaygı nedeniyle düzgün ve dikdörtgen geometride olması gerekliliği için hem alan, hem de mekan esnekliğini gözönünde bulundurarak ürünler için en uygun raf yerini tespit eden bir formül geliştirmişlerdir.

Depolarda alan tasarrufu, optimizasyonu ve depo yerleştirme problemine dair farklı yaklaşımlar mevcuttur. Ancak raf alanı düzenlemesi çok sık periyotlarla gerçekleştirilen bir operasyon olduğu için uygulaması kolay ve tekniği basit olan uygulamaların tercih edilmesi uygun olmaktadır. Bu yaklaşımlardan alan esnekliği yaklaşımı zor bir yöntem olması nedeniyle eleştiriler almaktadır. Raf alanı yerleşimi için metod seçiminde kullanılan ticari modeller ve deneysel modeller de performans etkilerinin değerlendirilememesi nedeniyle olumsuz bulunabilmektedir. Bu kapsamda en uygun teknik olarak optimizasyon modelleri gösterilmektedir.(Özyörük ve Ak, 2012)

Raf alanı planlaması ve öğelerin rafa atanması, kategori planlama işlemlerinin bir parçasıdır. Temelinde raflardaki öğelerin doğru konumunu, sınırlı raf boyutu kısıtları altında listelenen ürünlere yönelik atamanın yapılması vardır. Bu işlemi ögeleri farklı raf seviyelerine ayırarak ve miktarları bunlara göre atayarak gerçekleştirir. Bu amaçla verilen çalışmalarda dikey raf pozisyonunun (hangi raf seviyesi) ve yatay raf pozisyonunun (hangi ögelerin yanyana olduğunu ve koridorda konumlandırılan bir ögenin ne kadar uzakta olduğunu) tanımlandığı görülmektedir. (Irion vd, 2012, Hübner ve Schaal, 2017)

Raf alanı optimizasyonu kapsamında Flamand ve arkadaşlarının (2018) yaptığı çalışmada tek raflı bir problemi yinelemeli şekilde optimize edilmek amaçlanmıştır. Seçilen bir raf alt kümesinde her bir ürün kategorisi için olası talep tüm olası senaryolar üzerinden 
sezgisel tarama prosedürü ile raf alanı atamaları gerçekleştirilmiştir. Ghoenim vd (2016) benzer amaçla yakın komşu prosedüründen faydalanmışlardır. Çalışmada her bir ögenin bir ürün ailesini temsil ettiği ve raf alanlarının sırt çantası modeli ile tanımlandığı, alt ve üst sinırlarda en fazla ögeyi yerleştirecek şekilde geniş kapsamlı bir komşuluk ağı algoritması geliştirilmiştir. 210 öge ve 42 sirt çantasına gerçekleştirilen vaka incelemesinde sezgisel optimizasyon tekniği ile atama problemi ele alınmıştır.

\section{Materyal ve Metot}

$\mathrm{Bu}$ çalışmada bir işletmenin belli bir kısmındaki raf alanının optimize edilmesi amacıyla Sırt Çantası modeli ve Tam sayılı Programlama yöntemi kullanılmıştır. Bahsedilen tekniklerle kurulan modeller LINGO paket programında çözülmüştür. Firmaya ait mevcut durum ve önerilen yeni durumun simülasyonları ProModel simülasyon programı ile gösterilmiş olup neticesinde elde edilen sonuçlar yorumlanmıştır.

\subsection{Sırt Çantası Modeli}

Sirt çantası problemi, tam sayılı programlama problemleri içinde çok tercih edilmiş tekniklerden bir tanesidir. Sırt çantası probleminin çıkış noktası bir tura katılmak için sırt çantasını hazırlayan ve hangi eşyaları yanına alması gerektiğini belirlemek zorunda olan bir dağcı ve tur için kullanışlı olabilecek bir sürü nesne ve kapasitesi sınırlı olan bir de çantadır. Bir sırt çantasının taşıma kapasite göz önüne alınarak tam kapasite yada kapasiteyi aşmayacak şekilde en optimal içeriğin, yükte hafif, pahada ağır mantığıyla, çantanın alabileceği nesneleri, taşıyacak kişiye sağlayacağı fayda kapsamında değerlendirerek modelleme esasına dayanır . Tespit edilen ağırlık taşıma kriterine göre, sağlayacağı faydayı en fazla yapacak şekilde her bir nesnenin ağırlığını ve vereceği faydayı göz önünde bulundurup optimal nesnelerin seçilmesi sağlanır. Objenin alınması yada alınmaması durumu ise " 0 " ve 1 ile temsil edilir. (Kocamaz, 2014; Bulut vd., 2018)

Nesnelerin her biri 1'den n'ye kadar numaralandırılmış ve her birinin sağladığı pj>0 sayısıyla, ağırlıkları ise aj $>0$ sayısıyla ölçülmektedir. Dağcının çantasını maksimum faydayla ve çanta kapasitesi olan 'c' yi aşmayacak şekilde doldurmak istemesi ile, hangi eşyalardan kaçar adet alması gerekliliği problemin mantığını özetlemektedir.

$\mathrm{Bu}$ makale çalışmasında da raflar sırt çantası olarak görülmüş ve en verimli raf sistemi aranmıştır. Aşağıda sırt çantası modeline dair amaç fonksiyonu ve kısıtlar genel ifade olarak sunulmuştur.

Amaç fonksiyonu $\rightarrow$ Enb $z=c 1 x 1+c 2 x 2+\cdots+c n x n$

Kisitlar

$1-\quad a 1 \times 1+a 2 \times 2+\cdots+a n x n \leq b$

$2-\quad x i=0$ veya $1(i=1,2, \ldots, n)$

Pratikte çok çeşitli alanlarda uygulaması yapılabilen, teorik bir alt yapıya sahip bir tekniktir. Sermaye bütçeleme, portföy seçme, kaynakların dağıtımı-atanması, mal yüklenmesi gibi problemlere sırt çantası modeli ile çözüm aranan finans, yatırım, üretim gibi çok farklı alanlarda örnekleri bulunmaktadır. Sırt çantası yöntemi oldukça net anlaşılır bir teknik olmasına rağmen, karakteristik yapisı nedeniyle çözümde zorlukları olan bir yöntemdir. O yüzden, özellikle son yıllarda sezgisel algoritmalardan destek alınmaktadır. Tavlama benzetimi, genetik algoritmalar, parçacık sürü algoritması gibi yöntemler örnek olarak verilebilir. (Yaman, 2014)

Gilmore ve Gomory'nin 1966 yılında dinamik programlama ile ele aldıkları sırt çantası problemine yönelik çalışmaları ve Ingargiola vd.'nin 1973 yılına ait sırt çantası modelini indirgeme tekniği ile uyguladıkları çalışma literatürde temel çalışmalar olarak yerlerini almıştır. Yang (2001), bir sırt çantası problemini çözmek için sezgisel bir algoritma geliştirmiştir. Her bir ürün için satış karı ağırlığına göre sıralama yaparak raf atamalarını gerçekleştiren 5 aşamalı bir algoritma sunmuştur. Yang'ın sunduğu sezgisel bulguları değerlendiren Lim ve arkadaşları (2004) yaptıkları çalışmada hibrit bir çözüm stratejisi ile raf yerleşiminin iyi planlanmış olması durumunda mağazaların performansında iyileşmelerin görülebildiği ve ürünlerin stokta kalma ihtimalinin azaldığı ifade edilmiştir.

Sirt çantası probleminde optimizasyon modeli esas alarak gerçekleştirilen temel literatür örneklerine Anderson ve Amato (1974) nun ana talep etkilerini göz önünde bulundururak ele aldıkları sırt çantası optimizasyon modelini, Hansen ve Heinsbroek (1979)'in matematiksel model ile yaptıkları çalışmayı, Corstjens ve Doyle (1981)ın talebin ana etkilerini de sunarak geliştirdikleri bir geometrik programlama modelli çalışmaları ve bu çalışmadaki modele dinamik programlama ile bir modelle problem çözülen Zufryden (1986) e ait çalışma ve Khuri ve arkadaşları tarafindan. (1994) yapılan sırt çantası problemi ve genetik algoritma tekniği ile problem çözülen çalışmaları sırt çantası yöntemi ile optimizasyon gerçekleştirilen örneklerdendir.

\subsection{Tam Sayılı Programlama}

Tamsayılı Programlama(TSP), doğrusal ve doğrusal olmayan değişkeninin bir kısmının veya tümünün kesikli olarak tanımlandığı problemlere "kesikli optimizasyon" veya "tamsayılı optimizasyon" problemi denir. Tam Sayılı Doğrusal Programlama, değişkenlerinden bazılarının veya tümünün pozitif tam sayılı (yada kesikli) değerler aldığı bir doğrusal programlama yaklaşımıdır. (Taha, 1992) 
Bazı durumlarda problemlerden elde edilen değerler kesirli olabilmektedir. Ancak kesirli değerlerin anlamsız olduğu, çıtı değerleri ve/veya karar değişkenlerinin $\mathrm{n}$ tam sayı olması gereken konular bulunmaktadır. Örneğin personel sayısı tamsayı olmak zorundadır. Böylesi problemlerin çözümünde Tam Sayılı Programlama modelleri kullanılır. (Conforti vd. 2014) .

Doğrusal programlama problemlerinin ç̧̈züm sonuçları, çoğunlukla, tam sayı olmayan rasgele pozitif sayılardır. Ancak pratikte, sonuçların tamsayılar olmasını gerektiren birçok problem bulunmaktadır. Örneğin; otomobil, buzdolabı, takım tezgâhları v.b. üretiminde üretilecek miktarların pozitif tamsayılarla $(0,1,2,3,4)$ ifade edilmesi gerekir. Böylesi mamullerin, doğrusal programlama yöntemlerinden yararlanılarak üretilecek miktarların saptanmasında tamsayılı programlama kullanılır. (Patır, 2009)

Kaynak dağıtımının etkin bir şekilde gerçekleştirilmesi için kullanılan yöntemlerden olan atama problemleri farklı kümelerde yer alan, farklı nitelikteki ögelerin kaynak kullanımını optimal yapacak şekilde çözülmesi hedeflenen problemlerde (görevlere kişi atanması, taşıma seferleri için araç atama gibi) uygulanmaktadır. Bu problemlerde her iş bir işlem merkezine atanacağından dolayı ve her işlem merkezine sadece bir iş atanması gerektiğinden 0 ve 1 değerleri ile tanımlanan karar değişkenleri kullanılır. (Akar G.S., 2018) .

\section{Raf Alanı Optimizasyonu Uygulama Çalışması}

ABC ambalaj firmasının yarı mamul deposunda sabit aralıklı raflar vardır ve farklı boyutlardadır. Bu sebeple depo alanındaki raflar \%100 kapasite ile kullanılamamaktadır. Dengeli kapasite kullanımının olmamasından dolayı firmanın Laminasyon ve Baskı bölümlerinden gelen yarı mamuller rafların boş olmaması durumunda ya rafların bulunduğu koridor boyunca yerlere konulmaktadır ya da üretim binasının dışındaki ek binaya gönderilmektedir. Buralarda düzensiz şekilde bekletilen yarı mamül ve mamüller çalışma ortamında düzensizlik ve dağınıklık sebebiyle israflara sebep olmaktadır. Bunların giderilmesi amacıyla raf alanlarının optimal şekilde kullanılması için bir optimizasyon çalışması hedeflenmiştir.

\section{1. İşletmedeki Mevcut Durum:}

İşletmenin Laminasyon ve Baskı bölümlerinde yapılan üretimler sonucu çıkan ürünler yarı mamul deposundaki raflara yerleştirilmektedir (Şekil1). Firmanın mevcut durumda depo sistemi 2'şer katlı 72 paletlik sıra olmak üzere toplam 144 sıra paletlik alandan ibarettir. Ancak rafların yetersiz olması sebebiyle hem firmanın vizyonunda öncelik tanıdığ 1 iş sağlığı güvenliğini tehdit etmekte hem de $5 \mathrm{~S}$ ve Kaizen gibi yalın üretim kurallarını ihlal etmektedir ve üretimde zaman kayıplarına, gereksiz iş gücü kayıplarına neden olmaktadır

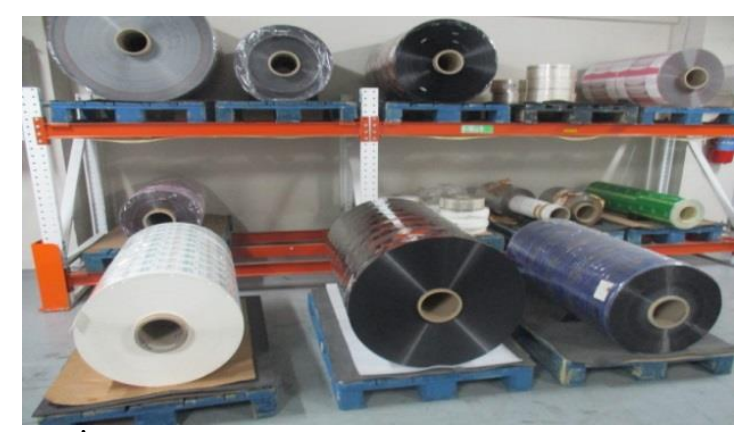

Şekil 1. İşletmede ki mevcut raf yerleşiminin görüntüsü

Laminasyon ve baskı bölümlerinde bir ay süresince belirli periyotlarda üretimden gelen bu yarı mamullerin depolamada kapladıkları alan tespiti ve iyileştirilmeleri için yükseklikleri ölçülmüşs ve verileri kaydedilmiştir. Bu bölümdeki yarı mamuller ölçümlere göre sınıflandırıldığında $0-50 \mathrm{~cm}$ aralığında olan yarı mamuller, $0-60 \mathrm{~cm}$ aralığında olan yarı mamuller, $0-70 \mathrm{~cm}$ aralığında olan yarı mamuller, $0-80 \mathrm{~cm}$ aralığında olan yarı mamuller ve $0-90 \mathrm{~cm}$ aralığında olan yarı mamuller olduğu tespit edilmiştir. Mevcut raflara bu aralıklarda kaçar adet ortalama ürün yerleştirildiğine dair bilgilerin bir kısmı aşağıdaki tabloda (Tablo1) verilmiştir. Tablo da belirli tarihlerde gelen yarı mamüller ve çapları görülmektedir. 
Tablo1: Yarımamuller için yapılan ölçümler sonucu elde edilen verilerin bir kısmı

\begin{tabular}{|l|l|l|l|l|l|l|l|l|l|}
\hline \multirow{2}{*}{ SAYI } & ÇAP & \multicolumn{10}{|l|}{ ( } & 4.10 .16 & 6.10 .16 & 10.10 .16 & 12.10 .16 & 18.10 .16 & 19.10 .16 & 25.10 .16 & 27.10 .16 & 31.10 .16 \\
\hline 1 & 23 & 24 & 23 & 26 & 25 & 26 & 26 & 26 & 26 \\
\hline 2 & 25 & 27 & 25 & 27 & 28 & 28 & 26 & 26 & 28 \\
\hline 3 & 30 & 29 & 26 & 32 & 29 & 30 & 30 & 28 & 28 \\
\hline 4 & 32 & 29 & 29 & 33 & 30 & 30 & 31 & 28 & 30 \\
\hline 5 & 32 & 30 & 31 & 34 & 32 & 33 & 31 & 30 & 31 \\
\hline 82 & 65 & 62 & 53 & 55 & 69 & 70 & 54 & 66 & 63 \\
\hline 83 & 65 & 62 & 54 & 55 & 70 & 70 & 55 & 66 & 63 \\
\hline 84 & 65 & 63 & 54 & 57 & 70 & 70 & 55 & 66 & 64 \\
\hline 85 & 66 & 63 & 54 & 57 & 71 & 71 & 55 & 66 & 65 \\
\hline 86 & 67 & 64 & 54 & 57 & 73 & 71 & 55 & 67 & 65 \\
\hline 87 & 67 & 64 & 54 & 57 & 74 & 71 & 55 & 67 & 65 \\
\hline 88 & 67 & 64 & 54 & 58 & 74 & 71 & 55 & 67 & 65 \\
\hline 89 & 67 & 65 & 54 & 58 & 75 & 71 & 56 & 67 & 65 \\
\hline 90 & 68 & 65 & 54 & 58 & 75 & 72 & 56 & 67 & 66 \\
\hline 91 & 68 & 66 & 54 & 58 & 75 & 72 & 56 & 68 & 66 \\
\hline 100 & 71 & 70 & 55 & 61 & 78 & 73 & 60 & 71 & 70 \\
\hline 101 & 71 & 70 & 55 & 61 & 79 & 74 & 60 & 71 & 71 \\
\hline 102 & 71 & 70 & 55 & 61 & 79 & 74 & 61 & 72 & 71 \\
\hline 103 & 71 & 71 & 55 & 62 & 79 & 75 & 62 & 73 & 72 \\
\hline 104 & 71 & 71 & 55 & 62 & 79 & 75 & 62 & 73 & 72 \\
\hline 105 & 72 & 72 & 55 & 63 & 81 & 75 & 62 & 73 & 72 \\
\hline
\end{tabular}

Tablo2.'de ilgili raf alanında bulunan yarı mamüllerin boyutlarına (çaplarına) göre gün bazında adetleri verilmiştir. Örneğin, 0-50 cm çap aralığındaki bobinlerin hangi tarihte ne kadar miktarda geldiği görülmektedir. Tablonun en son sütununda da ele alınan zamandaki ortalama miktarlar verilmiştir. (Tabloda elde edilen tüm tarihlere ait veriler değil, temsili alınan bazı tarihlere ait veriler konulmuştur.)

Tablo 2. Gün bazında raf alanında bulunan yarımamullerin boyutlarına göre adetleri

\begin{tabular}{|c|c|c|c|c|c|c|c|c|c|c|}
\hline BOBİN ÇAPI $\quad(\mathrm{cm})$ & 4.10.2016 & $\begin{array}{l}6.10 . \\
2016\end{array}$ & $\begin{array}{l}10.10 \\
2016\end{array}$ & $\begin{array}{l}12.10 . \\
2016\end{array}$ & $\begin{array}{l}18.10 \\
2016\end{array}$ & $\begin{array}{l}19.10 \\
2016\end{array}$ & $\begin{array}{l}25.10 \\
2016\end{array}$ & $\begin{array}{l}27.10 \\
2016\end{array}$ & $\begin{array}{l}31.10 . \\
2016\end{array}$ & ORT. \\
\hline $0-50$ & 51 & 50 & 61 & 63 & 45 & 51 & 63 & 52 & 47 & 54,4 \\
\hline $51-60$ & 23 & 25 & 66 & 36 & 18 & 14 & 38 & 20 & 30 & 33,6 \\
\hline $61-70$ & 25 & 27 & 23 & 16 & 21 & 19 & 14 & 26 & 23 & 21,7 \\
\hline $71-80$ & 36 & 31 & 21 & 25 & 20 & 34 & 9 & 27 & 19 & 24,3 \\
\hline $81-90$ & 5 & 8 & 7 & 5 & 20 & 22 & 6 & 13 & 5 & 9,8 \\
\hline TOP. & 140 & 141 & 178 & 145 & 124 & 140 & 130 & 138 & 124 & 143,8 \\
\hline
\end{tabular}

\subsubsection{Mevcut Durum ve ProModel Simülasyon Programı ile Gösterimi}

Firmada Baskı bölümü makinelerinden saatte bir gelen ürünler yarı mamul deposuna gönderilmektedir. Daha sonra Laminasyon bölümü makineleri boşaldıkça buradaki yarımamulleri sırasıyla çekerek işleme tabi tutmakta ve sonra tekrar yarımamul deposuna göndermektedir. Devamında Kesme bölümü makinelerinin boşaldıkça buradan mamul çekip ürüne dönüştürme döngüsü yer almaktadır. Mevcut durumda depoda bulunan raf sayıları kısıtlı ve sabit aralıklı olduğundan üretilen küçük çaplı ve büyük çaplı ürünler ayrım gözetmeksizin aynı boyuttaki raflara konulmaktadır. Bu da alan bakımından kayıplara sebebiyet vermektedir.

İşletmedeki mevcut durumun eldeki verilerle simülasyon programı PRoModel ile çalıştırılan simülasyon görüntüleri Şekil 2'de verilmiştir.

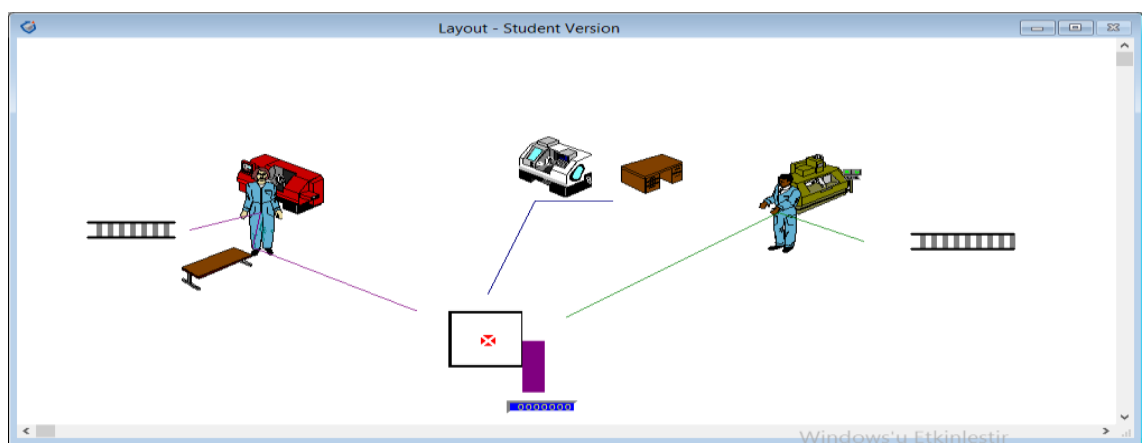

Şekil 2. Mevcut durumun ProModel programına aktarılmış görüntüsü

ProModel programında mevcut durumdaki entity’lerin simülasyona aktarımını gösteren ekran görüntüleri (Şekil 3) aşağıda verilmiştir. 


\begin{tabular}{|c|c|c|c|c|c|}
\hline 0 & & & & & {$[1]=0$} \\
\hline \begin{tabular}{|l|l|} 
Icon \\
\end{tabular} & Name & Speed ( $\mathrm{fpm}$ ) & Stats & Notes. & 7 \\
\hline$\otimes$ & Harmadde & 150 & Time Series & & $\therefore$ \\
\hline & 850 & 150 & Time Series & & 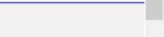 \\
\hline 0 & 860 & 150 & Time Series & & \\
\hline 0 & 870 & 150 & Time Series & & \\
\hline 0 & 880 & 150 & Time Series & & \\
\hline 0 & 890 & 150 & Time Series & & \\
\hline 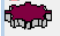 & ürün & 150 & Time Series & & v \\
\hline
\end{tabular}

Şekil 3. Mevcut durumdaki Entity’lerin simülasyona aktarılmasını gösteren ekran görüntüsü

Elde edilen simülasyon çıktıları aşağıda verilmiştir (Şekil 4).

\begin{tabular}{|c|c|c|c|c|c|c|c|c|}
\hline \multicolumn{9}{|c|}{ TEZNOW.BAK (Normal Run - Rep. 1) } \\
\hline Name & Scheduled Time (HR) & Capacity & Total Entries & Avg Time Per Entry (MIN] & Avg Contents & Maximum Contents & Current Contents & \% Utilization \\
\hline Baski & 15,14 & 14,00 & 181,00 & 59,92 & 11,94 & 14,00 & 5,00 & 85,27 \\
\hline Laminasyon & 15,14 & 6,00 & 77,00 & 59,20 & 5,02 & 6,00 & 6,00 & 83,63 \\
\hline Kesme & 15,14 & 6,00 & 26,00 & 60,00 & 1,72 & 6,00 & 0,00 & 28,62 \\
\hline Table & 15,14 & 999999,00 & 176,00 & 0,01 & 0,00 & 1,00 & 0,00 & 0,00 \\
\hline Desk & 15,14 & 999999,00 & 71,00 & 0,01 & 0,00 & 1,00 & 0,00 & 0,00 \\
\hline Raf1 & 15,14 & 144,00 & 246,00 & 250,41 & 67.81 & 143,00 & 143,00 & 47,09 \\
\hline Giris & 15,14 & 999999,00 & 185,00 & 16,41 & 3,34 & 4,00 & 4,00 & 69,44 \\
\hline Cikis & 15,14 & 999999,00 & 26,00 & 0,20 & 0,01 & 2,00 & 0,00 & 0,03 \\
\hline
\end{tabular}

Şekil 4 Mevcut durum simülasyonunun sonuç raporunu gösteren ekran görüntüsü

Simülasyon neticesinde elde edilen bölümlere ait raf doluluk oranlarını gösteren ekran görüntüsü Şekil 5'de, raflar dolduğunda sistemdeki hammadde, yarı mamul ve toplam üretim sayılarının yer aldığı ekran görüntüsü ise Şekil 6'de verilmiştir.

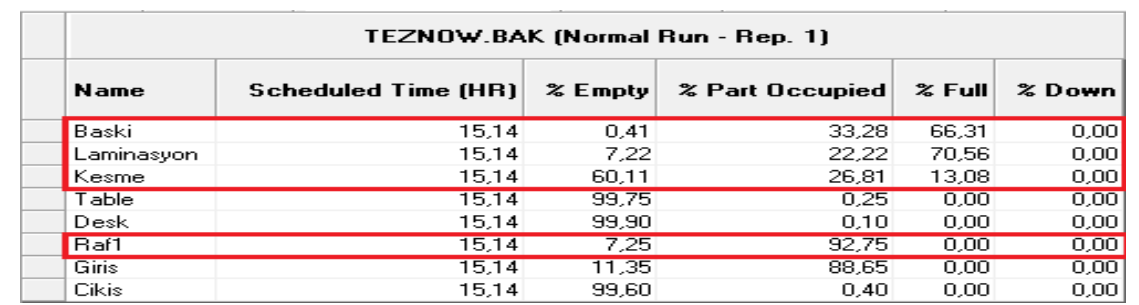

Şekil 5. Bölümlerin ve raf alanının doluluk oranlarını gösteren ekran görüntüsü

\begin{tabular}{|l|r|r|}
\hline Name & Total Exits & Current Qty In System \\
\hline Hammadde & 0,00 & 9,00 \\
\hline B50 & 0,00 & 30,00 \\
B60 & 0,00 & 30,00 \\
B70 & 0,00 & 24,00 \\
\hline B80 & 0,00 & 33,00 \\
\hline B90 & 0,00 & 33,00 \\
\hline iirin & 26,00 & 0,00 \\
\hline
\end{tabular}

Şekil 6. Raflar dolduğunda sistemdeki hammadde, yarı mamul ve toplam üretim sayıları

Bölümlerin ve raf alanlarının kullanım oranlarını gösteren ekran görüntüsü Şekil 7'de yer almaktadır.

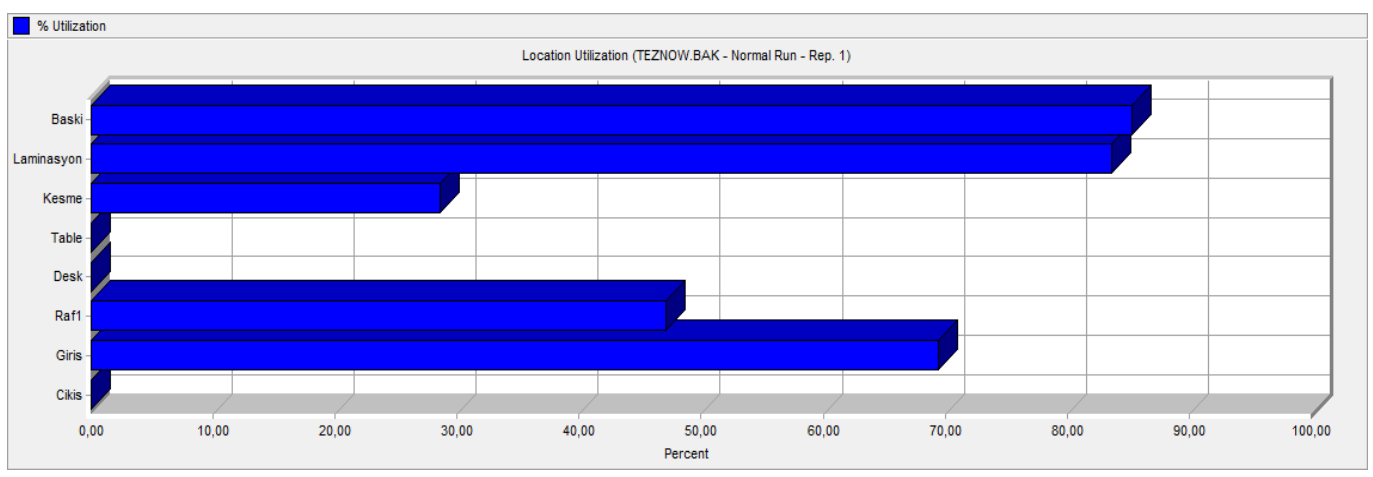

Şekil 7. Mevcut durumda Bölümlerin ve Raf alanının Kullanım oranları

İşletmede raf alanları tam performans kullanılmadığı için uğranılan kayıpların küçüklenmesi amacıyla Tam Sayılı Doğrusal Programlama ve Sırt Çantası modelleriyle raf alanının optimize edilmesi amaçlanmıştır. Bu amaçla, ilk olarak toplanılan verilerle Sırt Çantası yönteminden (Knapsack) yararlanarak model kurulmuştur. Modelin amaç fonksiyonu ve kısıtları oluşturulmuş ve aşağıda sunulmuştur. Oluşturulan lineer modelin çözümünde LINGO paket programı kullanılmıştır. 


\subsection{Sırt Çantası Modeli}

Bu aşamada, işletmede var olan kısıtlar, sınırlılıklar ve kaynaklar göz önüne alınarak, en fazla alan kullanımı (en fazla yarı mamul yerleştirilmesi) sağlanacak şekilde matematiksel model doğrusal olarak aşağıda verilmiştir:

Model bu çalışmaya uyarlandığında;

$\mathrm{p}:$ j. nesnenin sağladığı fayda, $\quad \mathrm{p} \in(500,600,700,800,900)$

$\mathrm{a}: \mathrm{j}$. nesnenin ağırlığ $1, \quad a \in(0.38,0.21,0.16,0.18,0.07)$

b : Sırt çantasının toplam kapasitesi $b=216$

enbZ $=;$ Enb z $=c 1 \times 1+c 2 x 2+\cdots+\operatorname{cnxn}$

Kapasite k1s1t1; $\quad \mathrm{a} 1 \mathrm{x} 1+\mathrm{a} 2 \mathrm{x} 2+\cdots+$ anxn $<216 \quad \mathbf{3 . 2 . 3}$

$0 \leq \mathrm{xj} \leq \mathrm{cj}$ ve tamsayı $\mathrm{j} \in \mathrm{J}$

Amaç fonksiyonu: Mevcut koşullar altında amaç fonksiyonu oluşturulduğunda, üretimi yapılan X1, X2, X3, X4 ve X5'ten elde edilecek karı maksimum yapacak denklem elde edilir (Denklem 3.2.4).

Kisitlar:

Aylık üretim ağırlıklarına göre X1, X2, X3, X4 ve X5'in yerleşim alanının 216 adet palet kapasitelik alana eşit yada daha az olması gerektiğini ifade eden kısıt Denklem 3.2.5.'de verilmiştir.

Denklem 3.2.6 ve 3.2.7. X1 ürününün günlük ortalama üretimine göre alt ve üst sınırlarının kısıtını,

Denklem 3.2.8 ve 3.2.9, X2 ürününün günlük ortalama üretimine göre alt ve üst sınırlarının kısıtını,

Denklem 3.2.10 ve 3.2.11, X3 ürününün günlük ortalama üretimine göre alt ve üst sınırlarının kısıtını,

Denklem 3.2.12 ve 3.2.13, X4 ürününün günlük ortalama üretimine göre alt ve üst sınırlarının kısıtını,

Denklem 3.2.14 ve 3.2.15, X5 ürününün günlük ortalama üretimine göre alt ve üst sınırlarının kısıtını ifade etmektedir.

$\begin{array}{lc}\max =500 * x 1+600 * x 2+700 * x 3+800 * x 4+900 * x 5 ; & \mathbf{3 . 2 . 4} \\ 0.38 * x 1+0.21 * x 2+0.16 * x 3+0.18 * x 4+0.07 * x 5<=216 ; & \mathbf{3 . 2 . 5} \\ x 1<=63 ; & \mathbf{3 . 2 . 6} \\ x 1>=45 ; & \mathbf{3 . 2 . 7} \\ x 2>=14 ; & \mathbf{3 . 2 . 8} \\ x 2<=66 ; & \mathbf{3 . 2 . 9} \\ x 3>=14 ; & \mathbf{3 . 2 . 1 0} \\ x 3<=27 ; & \mathbf{3 . 2 . 1 1} \\ x 4>=9 ; & \mathbf{3 . 2 . 1 2} \\ x 4<=36 ; & \mathbf{3 . 2 . 1 3} \\ x 5>=5 ; & \mathbf{3 . 2 . 1 4} \\ x 5<=22 ; & \mathbf{3 . 2 . 1 5}\end{array}$

Modelin LINGO paket programında çözümlenmesi

Modele dair oluşturulan amaç fonksiyonu ve kısıtlar LINGO paket programına girilmiş ve programdan elde edilen sonuçları sunan ekran görüntüsü Şekil 8'de verilmiştir. 


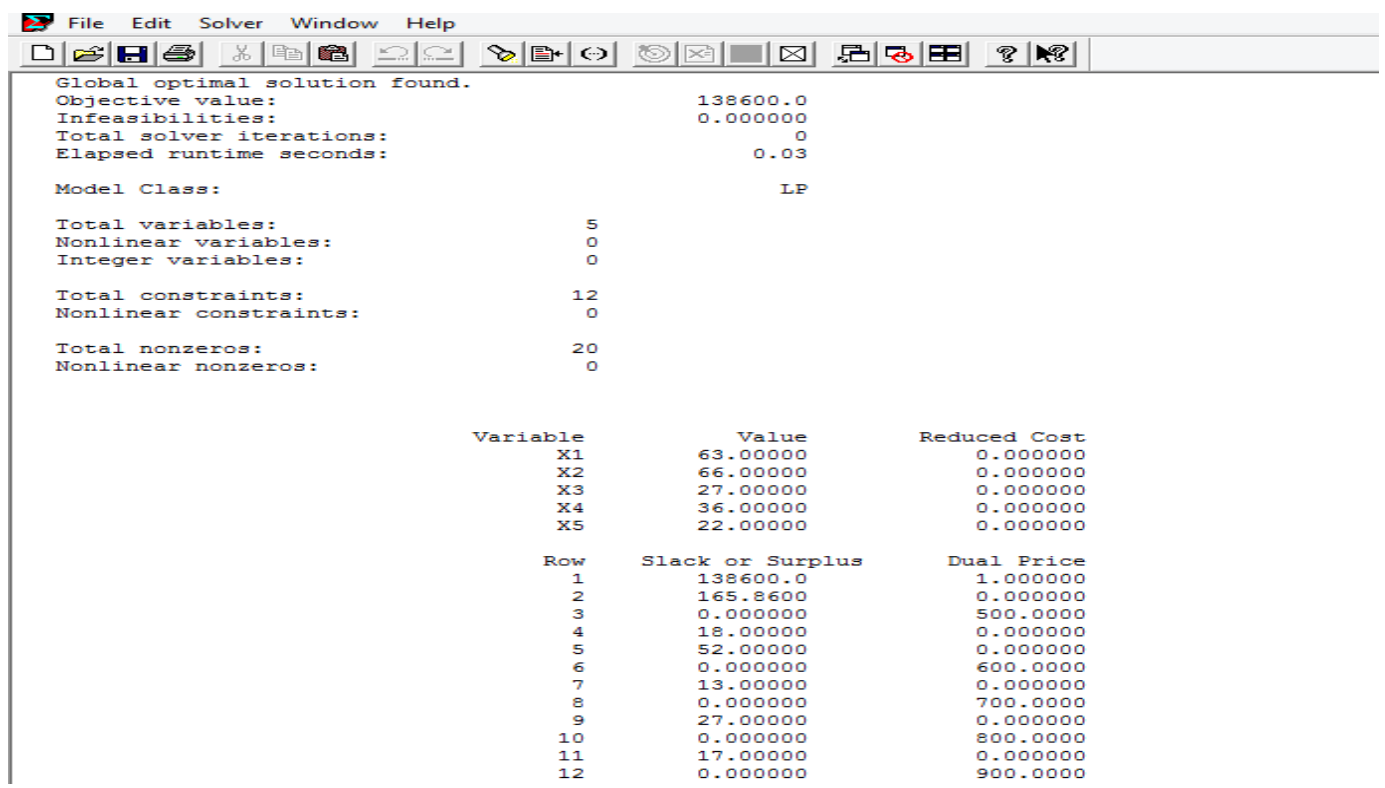

Şekil 8. LINGO paket programında problemin çözüm raporunu gösteren ekran görüntüsü

Bu sonuçlar yorumlandığında ;

$50 \mathrm{~cm}$ boyutundaki yarımamullere (X1) aylık olarak 63 paletlik alan,

$60 \mathrm{~cm}$ boyutundaki yarımamullere (X2) aylık olarak 66 paletlik alan,

$70 \mathrm{~cm}$ boyutundaki yarımamullere (X3) aylık olarak 27 paletlik alan,

$80 \mathrm{~cm}$ boyutundaki yarımamullere (X4) aylık olarak 36 paletlik alan,

$90 \mathrm{~cm}$ boyutundaki yarımamullere (X5) aylık olarak 22 paletlik alan ayrılması gerektiği bilgileri söylenebilir.

Tespit edilen bu boyuttaki yarı mamuller üçlü şekilde üst üste geldiklerinde (yarı mamullerin konulduğu palet ve raf boyutları çıkarıldığında) yüksekliğin en fazla $230 \mathrm{~cm}$ olması gerekmektedir. 5'in 3'lü kombinasyonuna göre yarı mamuller 10 farklı şekilde üst üste gelebilmektedir. Ancak bu kombinasyonlardan sadece 4 tanesi (4 raf tipi olarak ifade edilbilir) $230 \mathrm{~cm}$ 'ye eşit olmaktadır. Bu şartlarda yerleştirme şekilleri için oluşturulan alternatifler aşağıdaki şekillerde (Şekil 9, 10, 11 ve 12)verilmiştir.

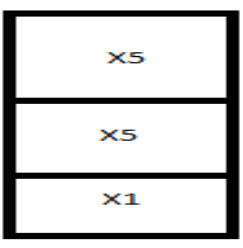

Şekil 9.Raf1 tipi

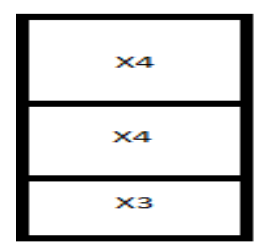

Şekil 10 .Raf2 tipi

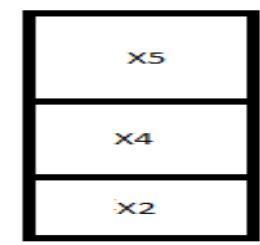

Şekil 11. Raf3 tipi

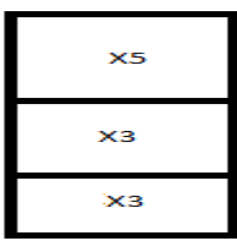

Şekil 12. Raf4 tipi

\subsection{Tam Sayılı Programlama}

Bu aşamada, yukarıda elde edilen raf tiplerinden kaçar adet olması gerektiğine dair işlemler gerçekleştirilmiştir. Bunun için Tam Sayılı Programlama ile kurulan modele dair amaç fonksiyonu ve kısıt denklemleri oluşturulmuştur. Y1, Y2, Y3, Y4 her bir raf sisteminin yükseklik cinsinden ifadesini göstermektedir. Kullanılan alanı maksimum hale getiren amaç fonksiyonu Denklem 3.3.1.'de ifade edilmiştir.

$\mathrm{Y} 1 \rightarrow 90,90,50$

$\mathrm{Y} 2 \rightarrow 80,80,70$

$\mathrm{Y} 3 \rightarrow 90,80,60$

$\mathrm{Y} 4 \rightarrow 90,70$,

Bobinlerin çapları ve sığabilecek maksimum sayıları göz önünde bulundurularak elde edilen raf sayılarına dair denklemler ve karşılıkları ise şu şekildedir:

Denklem 3.3.2, 90'lık bobinin Y1'de 2 adet, Y3'de ve Y4'de 1 adet yerleşim alanı olduğunu göstermektedir.

Denklem 3.3.3, 80'lik bobinin Y1'de 2 adet ,Y2'de 2 adet,Y3'de 2ve Y4'de 1 adet yerleşim alanı olduğunu göstermektedir.

Denklem 3.3.4., 70'l1k bobinin Y1'de 2 adet, Y2'de 3 Y3'de 2 ve Y4'de 3 adet yerleşim alanı olduğunu göstermektedir.

Denklem 3.3.5, 60'lı bobinin Y1'de 2 adet,Y2,de 3 adet Y3'de 3 ve Y4'de 3 adet yerleşim alanı olduğunu göstermektedir.

Denklem 3.3.6, 50'lık bobinin Y1'de 3 adet,Y2'de 3 adet Y3'de ve Y4'de 3 adet yerleşim alanı olduğunu göstermektedir.

Denklem 3.3.7, Yan yana konulan raf sayısının en fazla 74'ü geçmemesi kısıtını göstermektedir. 
Denklem 3.3.8, Y1 değişkeninin tam sayı olma kısıtını göstermektedir.

Denklem 3.3.9, Y2 değişkeninin tam sayı olma kısıtını göstermektedir.

Denklem 3.3.10, Y3 değişkeninin tam sayı olma kısıtını göstermektedir

Denklem 3.3.11, Y4 değişkeninin tam sayı olma kısıtını göstermektedir.

Amaç fonksiyonu;

$\max =\mathrm{y} 1+\mathrm{y} 2+\mathrm{y} 3+\mathrm{y} 4$

Kisitlar;

$\begin{array}{ll}2 * y 1+y 3+y 4>=22 ; & \mathbf{3 . 3 . 2} \\ 2 * y 1+2 * y 2+2 * y 3+y 4>=36 ; & \mathbf{3 . 3 . 3} \\ 2 * y 1+3 * y 2+2 * y 3+3 * y 4>=27 ; & \mathbf{3 . 3 . 4} \\ 2 * y 1+3 * y 2+3 * y 3+3 * y 4>=66 ; & \mathbf{3 . 3 . 5} \\ 3 * y 1+3 * y 2+3 * y 3+3 * y 4>=63 ; & \mathbf{3 . 3 . 6} \\ \text { y1+y2+y3+y4<=74; } & \mathbf{3 . 3 . 7} \\ \text { @GIN y1 } & \mathbf{3 . 3 . 8} \\ \text { @GIN y2 } & \mathbf{3 . 3 . 9} \\ \text { @GIN y3 } & \mathbf{3 . 3 . 1 0} \\ \text { @GIN y4 } & \mathbf{3 . 3 . 1 1}\end{array}$

Kurulan model LINGO paket programında çözümlenerek bu raf tiplerinden kaçar adet olması gerekti hesaplanmıştır. Çözümü gösteren ekran görüntüsü şekil 13'de verilmiştir.

$\mathrm{Bu}$ sonuçlardan hareketle işletmenin yarımamul deposunda ürün yerleşimini optimum hale getirmek ve raf sayısını artırabilmek için;

Raf1stili (Y1) 33 sıra, Raf3 stili (Y3) 22 sıra ve Raf4 stili (Y4) 19 sıra olması gerektiği ve deponun optimum hale gelebilmesi için Raf2 stili (Y2) kullanılmaması gerektiği söylenebilir.

Ayrıca, yarı mamül deposunu optimum hale getirecek ürünlere ayrılacak adet/paletlik alan dağılımlarının aşağıdaki şekilde olması uygun olacaktır:

$50 \mathrm{~cm}$ boyutundaki yarımamuller $(\mathrm{X} 1)=33$ adet $/$ palet

$60 \mathrm{~cm}$ boyutundaki yarımamuller $(\mathrm{X} 2)=22 \mathrm{adet} / \mathrm{palet}$

$70 \mathrm{~cm}$ boyutundaki yarımamuller $(\mathrm{X} 3)=34$ adet $/$ palet

$80 \mathrm{~cm}$ boyutundaki yarımamuller $(\mathrm{X} 4)=22 \mathrm{adet} / \mathrm{palet}$

$90 \mathrm{~cm}$ boyutundaki yarımamuller $(\mathrm{X} 5)=105 \mathrm{adet} / \mathrm{palet}$

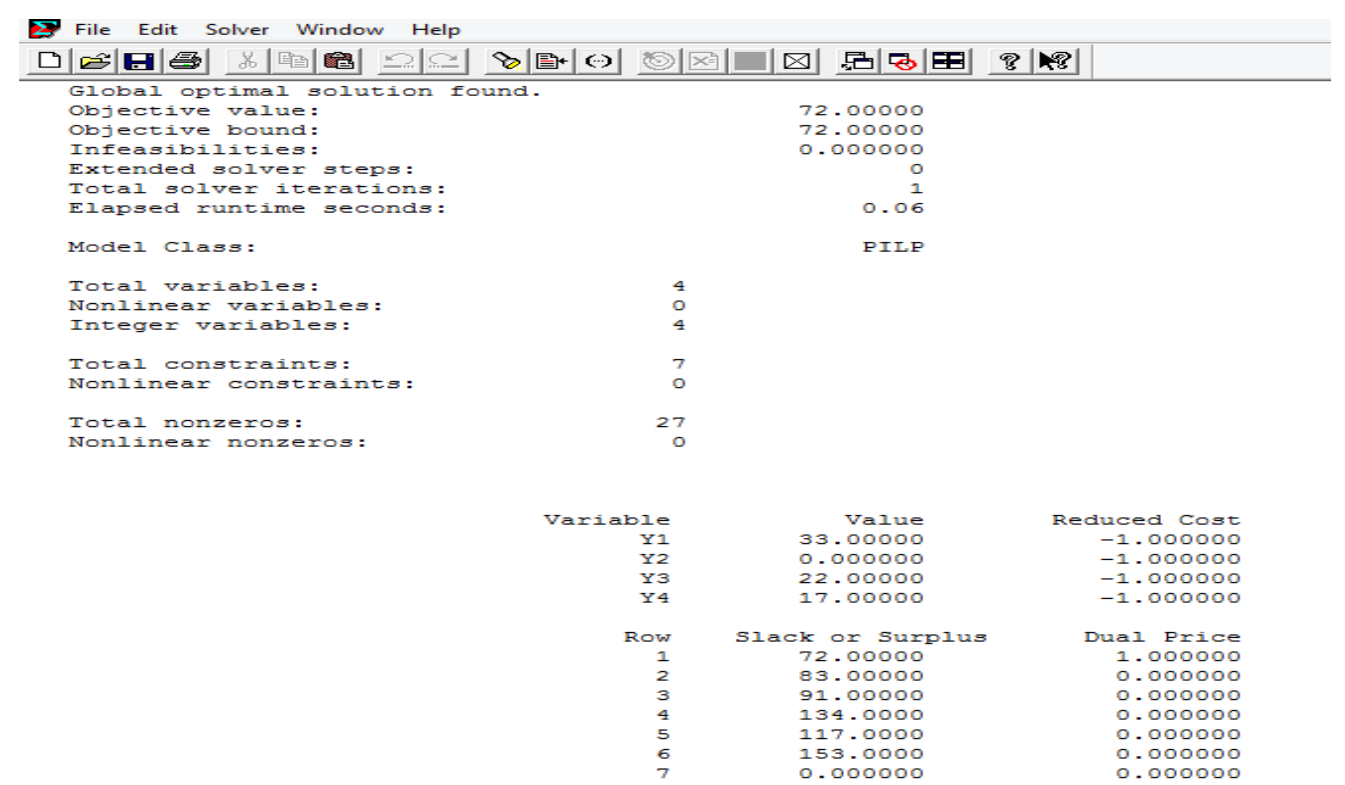

Şekil 13. Lingo Programında problemin çözüm raporunu gösteren ekran görüntüsü

\section{4. Önerilen Sistemin ProModel'de Simülasyonu}

Firmanın mevcut durumda depo sistemi 2'şer katlı olmak üzere 72 paletlik sıra olmak üzere toplam 144 sıra paletliklik alandan ibarettir. Yeni sistem olarak farklı boyutlardaki ürün çeşitliliğinden dolayı boşa kullanılan alanları kazanıp kat sayısını 3'e çıkararak 72 paletlik sıra olmak üzere toplam 216 sıra paletlik alana çıkarılması önerilmiştir. Önerilen yeni sistemin simülasyon programı Promodel'e aktarılmış durumu Şekil 14'da verilmiştir. 


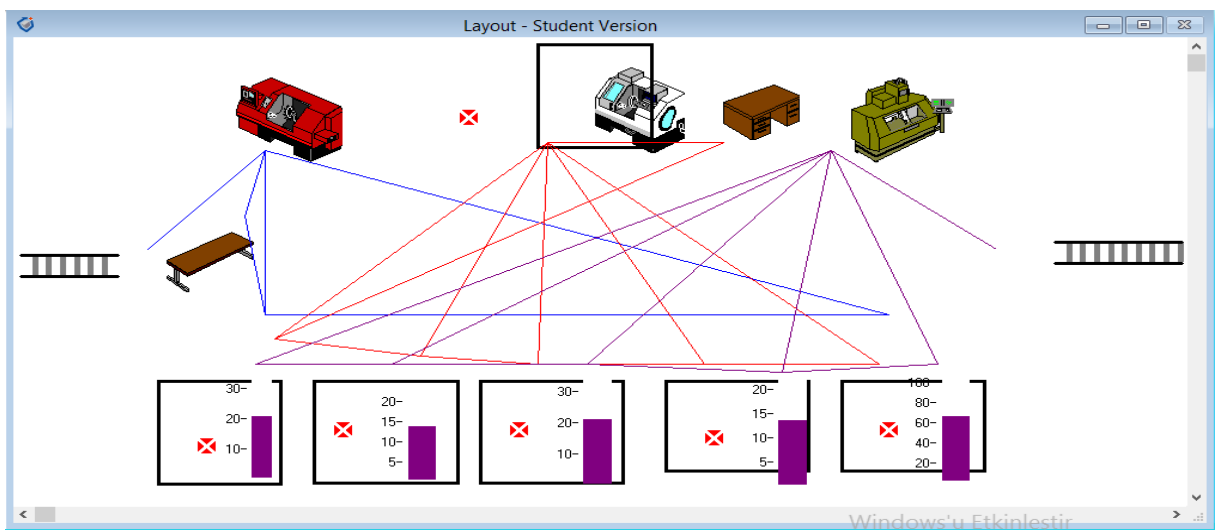

Şekil 14. Önerilmiş sistemin Simülasyona aktarılmış görüntüsü

$\mathrm{Bu}$ aşamada Baskı bölümü makinelerinden saatte bir gelen ürünlerin yarı mamul deposuna gönderilip öncelikle kendi boyutuna göre ayrılan alana yerleştirilmesi eğer kendi alanında yer kalmadıysa bir sonraki müsait alana gönderilmesi hedeflenmiştir. Bu şekilde devam eden döngüde yarı mamuller için öncelik yerleri belirtilmiş ve alanların müsaitliklerine göre bu rota izlenecektir. Daha sonra Laminasyon bölümü makineleri boşaldıkça buradaki yarımamulleri öncelik sırasıyla çekerek işleme tabi tuttuktan sonra tekrar yarımamul deposunda boyutuna göre ilk müsait olan alana gönderip Kesme bölümü makinelerinin boşaldıkça bu alanlardan mamul çekip ürüne dönüştürme döngüsü işlenmiştir. Şekil 15'de ise, önerilen sistemin simülasyonda çalıştırılmasına dair ekran görüntüsü verilmiş̧tir.

Bu yeni düzende önceki duruma göre raf kapasitesi 144 paletlik alandan 216 paletlik alana çıkarılmış ve bu alan ürünlerin üretim miktarlarının ortalamalarında göre ürün tiplerine dağıtılmıştır. Yeni duruma ait simülasyon çıktılarını gösteren ekran görüntüleri Şekil 16, Şekil 17 ve Şekil 18'de görülmektedir.

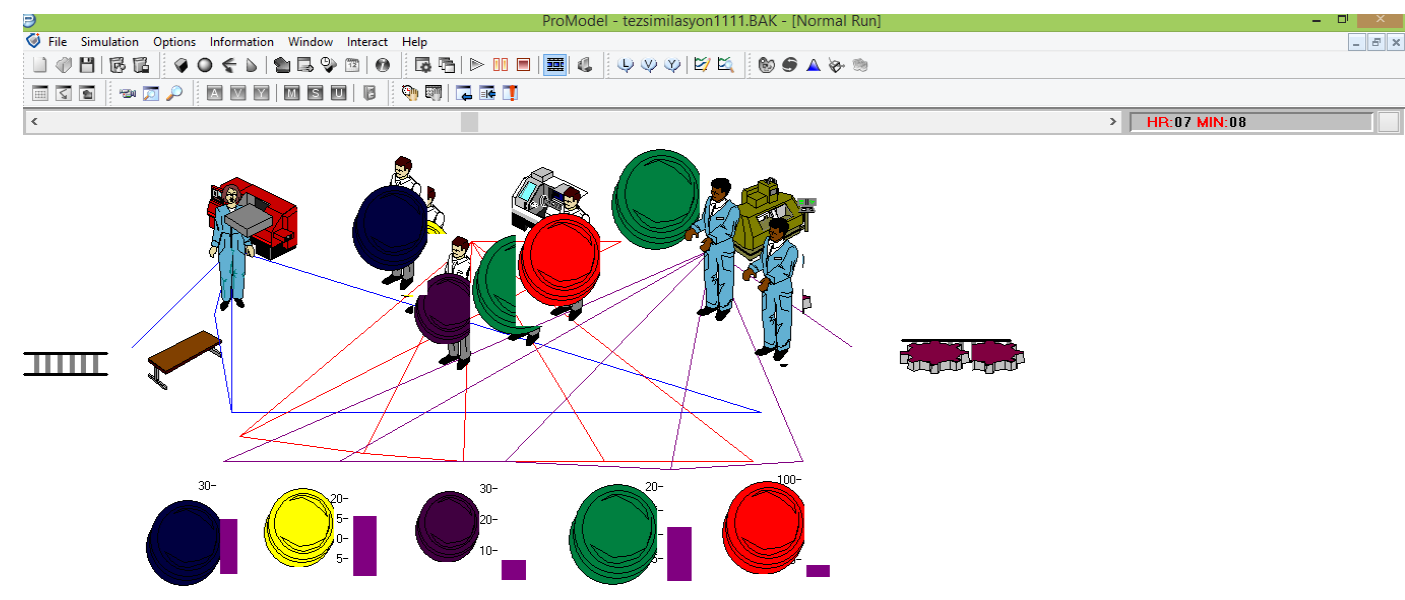

Şekil 15. Önerilen sistemin similasyonda çalıştırılma görüntüsü

\begin{tabular}{|c|c|c|c|c|c|c|c|}
\hline \multicolumn{8}{|c|}{ tezsimilasyon1111.BAK (Normal Run - Rep. 1] } \\
\hline Scheduled Time (HR) & Capacity & Total Entries & Avg Time Per Entry (MIN) & Avg Contents & Maximum Contents & Current Contents & $\%$ Utilization \\
\hline 15,14 & 14,00 & 182,00 & 59,92 & 12,01 & 14,00 & 5.00 & 85,75 \\
\hline 15,14 & 6,00 & 84,00 & 59,71 & 5,52 & 6,00 & 6,00 & 92,03 \\
\hline 15,14 & 6,00 & 49,00 & 59,54 & 3,21 & 6,00 & 6,00 & 53,53 \\
\hline 15,14 & 999999,00 & 186,00 & 16,30 & 3,34 & 4,00 & 4,00 & 76,31 \\
\hline 15,14 & 999999,00 & 43,00 & 0,20 & 0,01 & 2,00 & 0,00 & 0.05 \\
\hline 15,14 & 33,00 & 52,00 & 284,64 & 16,29 & 32,00 & 32,00 & 49,37 \\
\hline 15,14 & 22,00 & 45,00 & 281,29 & 13,93 & 22,00 & 22,00 & 63,34 \\
\hline 15,14 & 34,00 & 58,00 & 127.69 & 8,15 & 28,00 & 28,00 & 23,98 \\
\hline 15,14 & 22,00 & 43,00 & 213,80 & 10,12 & 21,00 & 18,00 & 46,00 \\
\hline 15,14 & 105,00 & 56,00 & 161,63 & 9,96 & 24,00 & 21,00 & 9,49 \\
\hline 15,14 & 999999,00 & 177,00 & 0.01 & 0,00 & 1,00 & 0,00 & 0,00 \\
\hline 15,14 & 999999,00 & 78,00 & 0,05 & 0,00 & 4,00 & 0,00 & 0,00 \\
\hline
\end{tabular}

Şekil 16. Önerilen sistemin simülasyonunun Location'larına ait raporu 


\begin{tabular}{|l|r|r|r|r|r||}
\hline \multicolumn{7}{|c|}{ tezsimilasyon1111.BAK (Normal Run - Rep. 1) } \\
\hline Name & Scheduled Time (HR) & \% Empty & \% Part Occupied & \% Full & \% Down \\
\hline Baski & 15,14 & 0,30 & 28,21 & 71,49 & 0,00 \\
\hline Laminasyon & 15,14 & 7,04 & 1,85 & 91,11 & 0,00 \\
\hline Kesme & 15,14 & 27,41 & 46,79 & 25,80 & 0,00 \\
\hline Giris & 15,14 & 11,60 & 88,40 & 0,00 & 0,00 \\
\hline Cikis & 15,14 & 99,35 & 0,65 & 0,00 & 0,00 \\
\hline Loc1 & 15,14 & 8,17 & 91,83 & 0,00 & 0,00 \\
\hline Loc2 & 15,14 & 7,60 & 78,40 & 14,00 & 0,00 \\
\hline Loc3 & 15,14 & 13,53 & 86,47 & 0,00 & 0,00 \\
\hline Loc4 & 15,14 & 9,31 & 90,69 & 0,00 & 0,00 \\
\hline Loc5 & 15,14 & 8,09 & 91,91 & 0,00 & 0,00 \\
\hline Table & 15,14 & 99,75 & 0,25 & 0,00 & 0,00 \\
\hline Desk & 15,14 & 99,64 & 0,36 & 0,00 & 0,00 \\
\hline
\end{tabular}

Şekil 17. Bölümlerin ve raf alanlarının doluluk oranları

\begin{tabular}{|l|r|r|}
\hline Name & Total Exits & Current Qty In System \\
\hline B50 & 0,00 & 33,00 \\
\hline B60 & 0,00 & 41,00 \\
\hline B70 & 0,00 & 14,00 \\
B80 & 0,00 & 21,00 \\
\hline B90 & 0,00 & 25,00 \\
\hline Hammadde & 0,00 & 9,00 \\
\hline iuruin & 43,00 & 0,00 \\
\hline
\end{tabular}

Şekil 18. Simülasyonun durdurulduğu zamanda sistemdeki hammadde, yarımamul ve toplam üretim sayıları

Önerilen yeni sistemde bölümlerin ve raf alanlarının kullanım alanlarını gösteren diyagrama dair görüntü Şekil 19'da verilmiştir.

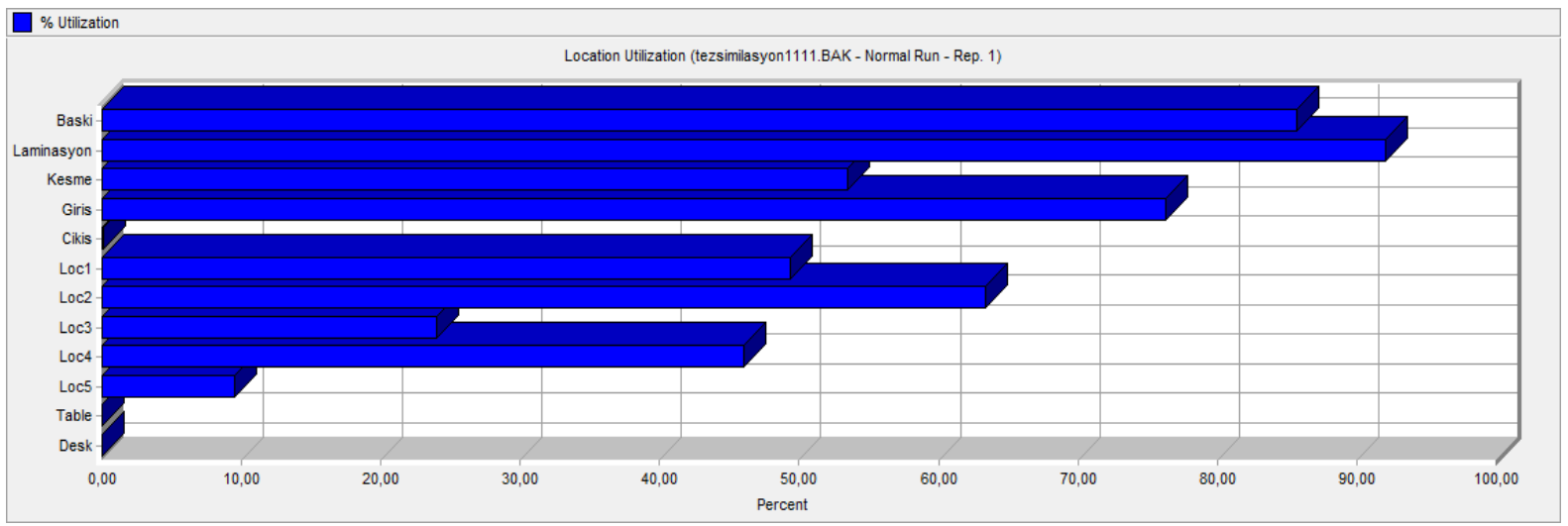

Şekil 19. Önerilen sistemde bölümlerin ve raf alanlarının kullanım oranlarını gösteren ekran görüntüsü

Elde edilen yeni verilere göre mevcut durum ile önerilen durumun Laminasyon, Baskı ve Kesme süreçlerindeki doluluk oranlarına yönelik bir kıyaslama aşağıdaki tabloda (Tablo 3) sunulmuştur.

Tablo 3: Önerilen sistem ile mevcut durumun üç temel sürece göre doluluk oranları

\begin{tabular}{|l|l|l|}
\hline & Mevcut Durum & Önerilen Durum \\
\hline Bask1 & 66,31 & 71,49 \\
\hline Laminasyon & 70,56 & 91,11 \\
\hline Kesme & 13,08 & 25,80 \\
\hline
\end{tabular}

\section{Sonuç}

Problemde gözlemlenen en temel sorun sabit aralıkta bulunan raflara yarımamul çapının küçük yada büyük olmasının raf sisteminin etkin kullanılmasına engel teşkil etmesidir. Her büyüklükteki yarımamul için aynı raf sistemin kullanılmasının sağlanması temel hedeftir. 
Geliştirilen çözümde farklı raf aralıkları belirleyerek boyutlarına göre yarımamulleri sınıflandırıp bu yarımamullerin öncelikle kendi boyutuna göre ayrılan alana yerleştirilmesi gerektiği, eğer kendi alanında yer kalmadıysa bir sonraki müsait alana gönderilmesi hedeflenmiştir. $60 \mathrm{~cm}$ boyutundaki ürün ilk olarak kendine ayrılan $60 \mathrm{~cm}$ 'lik rafların bulunduğu alana gidecek, eğer bu alanın kapasitesi doluysa bir sonraki $70 \mathrm{~cm}$ 'lik rafların bulunduğu alana gidecek eğer bu alanda doluysa $80 \mathrm{~cm}$ 'lik rafların bulunduğu alana gidecek, eğer bu alanda doluysa son olarak $90 \mathrm{~cm}$ 'lik rafların bulunduğu alana gidecek. Bu şekilde devam eden döngüde yarı mamuller için öncelik yerleri belirtilmiş ve alanların müsaitliklerine göre bu rota izlenecektir.

$\mathrm{Bu}$ yöntemle sabit raf aralıklarından kaynaklanan boşlukları raf alanlarına dönüştürüp 2 kattan oluşan ve 144 palet yarımamul yerleştirilen raf alanının kapasitesini yapılan gözlemler sonucunda alınan veriler doğrultusunda Yöneylem Araştırması tekniklerinden Tam Sayılı Doğrusal Programlama ve Sırt Çantası Modeli kullanılarak 3 kattan oluşan 216 palet yarımamul kapasitelik alana çıkarılmıştır. Palet bazında yaşanan kapasite artışının yanında ele alınan süreçlerde (Baskı, Laminasyon ve Kesme) rafların doluluk oranlarında da Tablo 3 ’te verildiği gibi farkedilir oranda iyileştirmeler sağlanmıştır.

Ayrıca, yapılan optimizasyon çalışması ile beklenen olası iyileştirmeler;

- Gereksiz iş gücü ve üretimdeki bekleyişlerin (duruşlar) azalması

- İş sağlı̆̆1 ve güvenliğini tehdit eden unsurların elemine edilmesi

- Taşımaların minimize edilmesi

- Görsel açıdan düzeninin sağlanması olarak ifade edilebilir.

$\mathrm{Bu}$ çalışmada raf alanı optimizasyonu için uygulama kolaylığı sağlayan yöneylem araştırmasının temel matematiksel modellerinden destek alınarak uygulama gerçekleştirilmiştir. Literatür çalışmalarında da sıklıkla ifade edildiği gibi yapay zeka tekniklerinden destek alınmış uygulamalar referans alınarak, benzer bir uygulama probleminde çalışmanın daha ileri seviyede çözümlenmesi amacıyla bahsedilen zeki optimizasyon tekniklerinin uygulanması gelecek çalışması olarak ele alınabilir. 


\section{Kaynakça}

Anderson, E.E. ,. Amato H.N. (1974). A mathematical model for simultaneously determining the optimal brand-collection and display-are allocation, Operations Research, 22 (1), pp. 13-21

Ashayeri, J., Gelders, L.F., (1985). Warehouse design optimization. European Journal of Operational Research, 21, $285-294$.

Bulut F. , Ince İ.F. (2018). Tam Sayı Programlamada Açgözlü ve Sezgisel Aramalar ile 0/1 Sırt Çantası Problemine Yeni Bir Bakış, Karaelmas Fen ve Mühendislik Dergisi Dergisi, 8(1):89-98, DOI: 10.7212\%2Fzkufbd.v811.830

Conforti, M. Cornuéjols, G., Zambelli, G. (2014). Integer Programming Models. Integer Programming. Springer International Publishing, pp. 45-84

Corstjens, M., Doyle, P., (1983). A dynamic model for strategically allocating retail space, Journal of the Operational Research Society, 34 (10) , pp. 943-951

Flamand, T., Ghoniem, A., Haouari, M., Maddah, B. (2018). Integrated assortment planning and store-wide shelf space allocation: An optimization-based approach, Omega, V: 81, pp: 134-149, https://doi.org/10.1016/j.omega.2017.10.006

Gajjar, H. K. Kadil, G., (2011). Heuristics for retail shelf space allocation problem with linear profit function. International Journal of Retail \& Distribution Management, 39(2):144-155.

Ghoniem, A., Flamand, T., Haouari, M. (2016), Optimization-Based Very Large-Scale Neighborhood Search for Generalized Assignment Problems with Location/Allocation Considerations, INFORMS Journal on Computing, V.28, N.3

Gilmore, P.C. Gomory R.E. (1966). The theory and computation of knapsack functions, Operations Research,14(6) 1045-1074.

Gray, A.E. Karmarkar, U.S., Seidmann, (1992). A. Design and operation of an order consolidation warehouse: models and application. European Journal of Operational Research , 58, 14-36

Hansen, P., Heinsbroek, H. (1979). Product selection and space allocation in supermarkets, European Journal of Operational Research, Volume 3, Issue 6, November 1979, Pages 474-484, https://doi.org/10.1016/0377-2217(79)90030-4

Heragu, S. S., L. Du, Mantel, R. J., Schuur P. C. (2005). Mathematical model for warehouse design and product allocation, International Journal of Production Research, 43: 2, 327-338, DOI10.1080/00207540412331285841

Hübner, A., Schaal, K. (2017). A shelf-space optimization model when demand is stochastic and space-elastic, Omega, V: 68, pp: 139-154, https://doi.org/10.1016/j.omega.2016.07.001

Hwang, H., Choi, B., Lee, M.J. (2005). A model for shelf space allocation and inventory control considering location and inventory level effects on demand. International Journal of Production Economics, 97(2):185-195.

Ingargiola, G. P., Korsh, J.F. (1973). Reduction Algorithm for Zero-one Single Knapsack Problems. Management Science 20.4 - Part-I 460-463.

Irion,J., Lu, J.C., Al-Khayyal, F. A., Tsao, Y.C., A piecewise linearization framework for retail shelf space management models European Journal of Operational Research, 222 (1) (2012), pp. 122-136

Janeiro, A.C.R., (2014). Optimization Algorithms for the Shelf Space Allocation Problem, Faculdade De Engenharia Da Universiadade Do Porto, Dissertation

Kang, K., Moon, I., Wang, H. (2012). A hybrid genetic algorithm with a new packing strategy for the three-dimensional bin packing problem, Appliead Mthematics and Computation 219(3):1287-1299, DOI: 10.1016/j.amc.2012.07.036

Khuri, S. Bäck, T., Heitkötter, J. (1994). The zero/one multiple knapsack problem and genetic algorithms. ACM Symposium on Applied Computing. pp. 188-193

Kocamaz M. (2014). Proje Portföyü Seçiminde Çok Boyutlu Sırt Çantası Modeli ve Bulanık Analitik Hiyerarşi Prosesi, Ege Akademik Bakış / Ege AcademiC Review Cilt: 14 Sayı: 3, 493-498.

Lim, A., Rodrigues B., Zhang, X., (2004). Metaheuristics with local search techniques for retail shelf-space optimization. Management Science, 50(1):117-131. 
Özyörük B, Ak S. (2012). Etkin Depo Yerleşiminin Düzenlenmesi İçin Bir Model: Elektronik Firmada Uygulanması, Tübav Bilim Dergisi, Cilt:5, Say1:1, Sayfa: 21-29.

Patır, S. (2009). Tam Sayılı Programlama Ve Malatya Maksan Transformatör İşletmesinde Bir Uygulama, İktisadi ve İdari Bilimler Dergisi, Cilt: 23, Say1: 1

Russell, R.A., Urban, T.L. (2010). The location and allocation of products and product families on retail shelves. Annals of Operations Research, 179(1):131-147.

Sezen Akar G. (2018). Dağıtım Merkezi Atama Problemi İçin Bir Optimizasyon Modeli, Ekonomi Maliye Işsetme Dergisi, Cilt:1Sayı:1.

Taha, H.A.(1992). Operations Research An Introduction, Fifth Edition, Macmillan Publishing Company, New York

Tekil, S., Özkır, Ç., (2016), Konteyner Yükleme Problemlerinin İncelenmesi VE Lojistik Sektöründe Bir Uygulama, Toros Üniversitesi Iisbf Sosyal Bilimler Dergisi, Y11:3 Say1:5

Van den Berg, J.P. Sharp, G.P. Gademann, A.J.R.M., Pochet, Y. (1998). Forward-reserve allocation in a warehouse with unit load replenishment. European Journal of Operational Research., 111, 98-113.

Yang, M. H. (2001), An Efficient algorithm to allocate shelf space. European Journal of Operational Research, 131(1):107-118.

Yaman I. (2014). Portföy Optimizasyonunda Değiştirilmiş Parçacık Sürü Optimizasyonu Yaklaşımı, Hacettepe Üniversitesi, Yüksek Lisans Tez

Zufryden F.S. (1986). A dynamic programming approach for product selection and supermarket shelf-space allocation, Journal of the Operational Research Society, 37 (4), pp. 413-422 